\title{
The Comparison of Credit Risk and Its Factors in Conventional and Islamic Banks
}

\author{
Atika Nurani Silmi ${ }^{1}$, M. Umar $\mathrm{Mai}^{2}$ and Iwan Setiawan ${ }^{3}$ \\ \{atika.nurani.kps18@polban.ac.id ${ }^{1}$, umar.mai@polban.ac.id², iwan.setiawan@polban.ac.id ${ }^{3}$ \} \\ Bandung State Polytechnic, Indonesia
}

\begin{abstract}
The objective of this study is to compare loan/financing risk and the factors that influence it between conventional banks and Islamic banks in Indonesia from 2010 to 2018. The influencing factors in both banks are macroeconomics, bank specific, and corporate governance. The sampling technique was purposive sampling and there were 33 banks obtained as the samples consisting of 24 conventional banks and 9 Islamic banks. This study used Structural Equation modeling-Partial Least Square technique and independent sample t-test. The study results showed that GDP affect the increase in NPL and the decrease in NPF. Inflation has no influence on NPL and NPF. Efficiency affects the increase in NPL and NPF. Bank size has effect on the decline of NPL and NPF. Board of directors influence the increase in NPL, but having no effect on NPF. Independent commissioners affect the decline of NPL, but having no influence on NPF.
\end{abstract}

Keywords: Macroeconomics, Bank Specific, Corporate Governance, Credit/Financing Risk

\section{Introduction}

Non Performing Loans (NPLs) is one of the basic indicators of bank's financial 'health' and it is the main measurement of loan risk in banking system. The increase in non performing loan indicated that there are several economic entities facing difficulty to pay off their loan that is more and more increasing, so the possibility of non performing loan increases [1]. Non Performing Loan (NPL) or Non Performing Financing (NPF) had become alarming problem in the previous decades because non performing loan has its own characteristics. More interestingly, the volume of non performing loan grows significantly not only in developing countries, but also in developed countries $[2,3]$. Some banking experts define NPL as "financial pollution" since it worsens economic value $[4,5]$.

Based on Indonesian Financial Services Authority (OJK) Regulation [6], non performing financing level can be reflected in the Non Performing 
Financing/ Non Performing Loan (NPF/NPL) ratio. Regulation of Indonesian Financial Services Authority Number 15/POJK.03/2017 regarding the Stipulation of Status and Follow-up Action to the Supervision of Commercial Banks, article 3 paragraph 2 point d stated that Banks are considered to have potential difficulties that endanger their business continuity if net NPL ratio or net NPF ratio is more than $5 \%$ of total loans or total financing [6].

In running their business, Islamic banks and conventional banks are more actively distribute financing/loan for the customers to increase income and optimize assets owned by banks [7]. This is reflected in Indonesian Banking Statistics 2020 in which the number of financing/loan continues to increase every year. Throughout 2014 to April 2020, the number of financing/loan in Islamic Banks and Conventional Banks shows an upward trend.

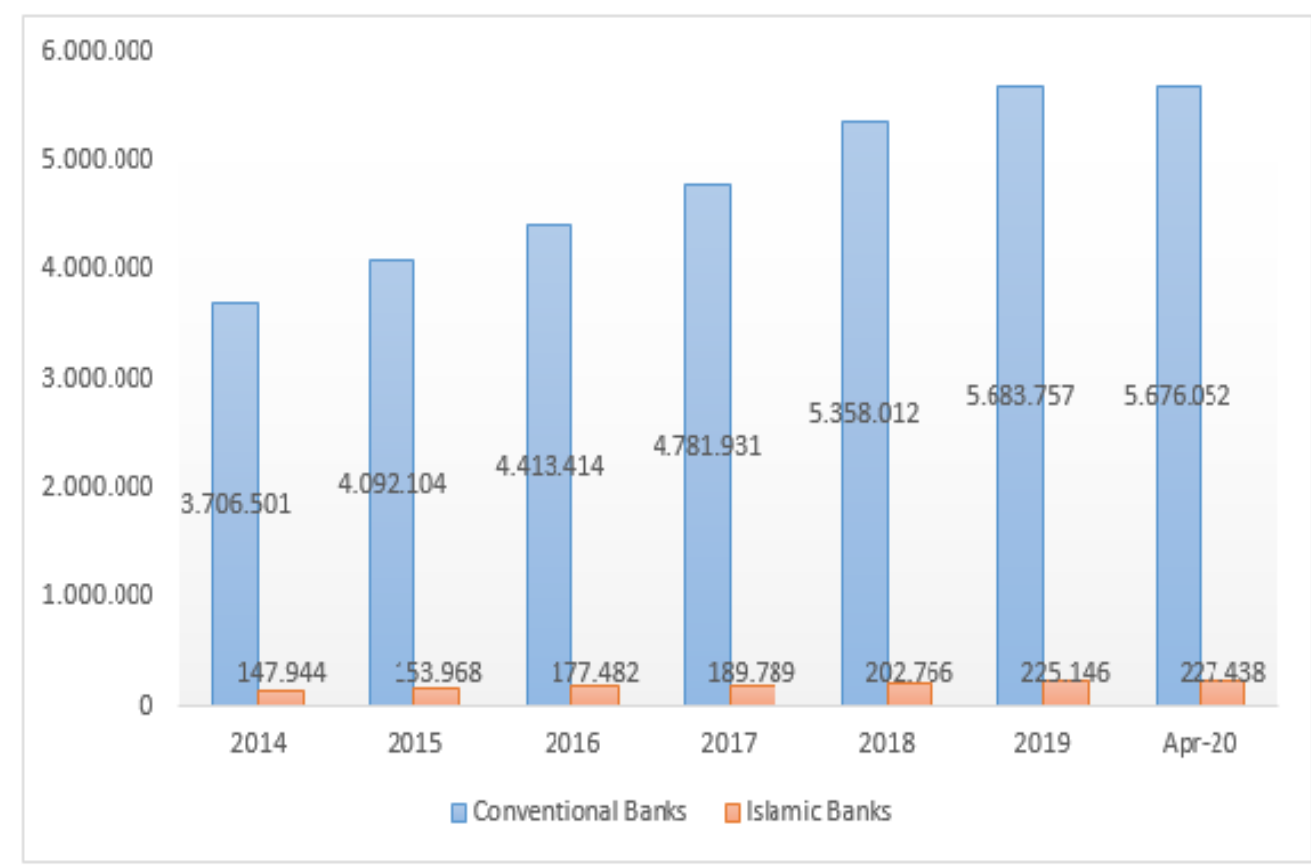

Figure 1

Financing and Loan Distribution (in Billion IDR) Source: Indonesian Banking Statistics, 2020 (processed data)

Based on Figure 1, it can be seen that financing and loan distribution in Islamic banks and conventional banks is always increasing every year. However, the quality of financing/loan in both banks is decreasing. This is reflected by the increase in loan distribution along with the increase in non 
performing loan in Islamic banks and conventional banks as depicted in Indonesian Banking Statistics 2020 that can be seen in Figure 2.

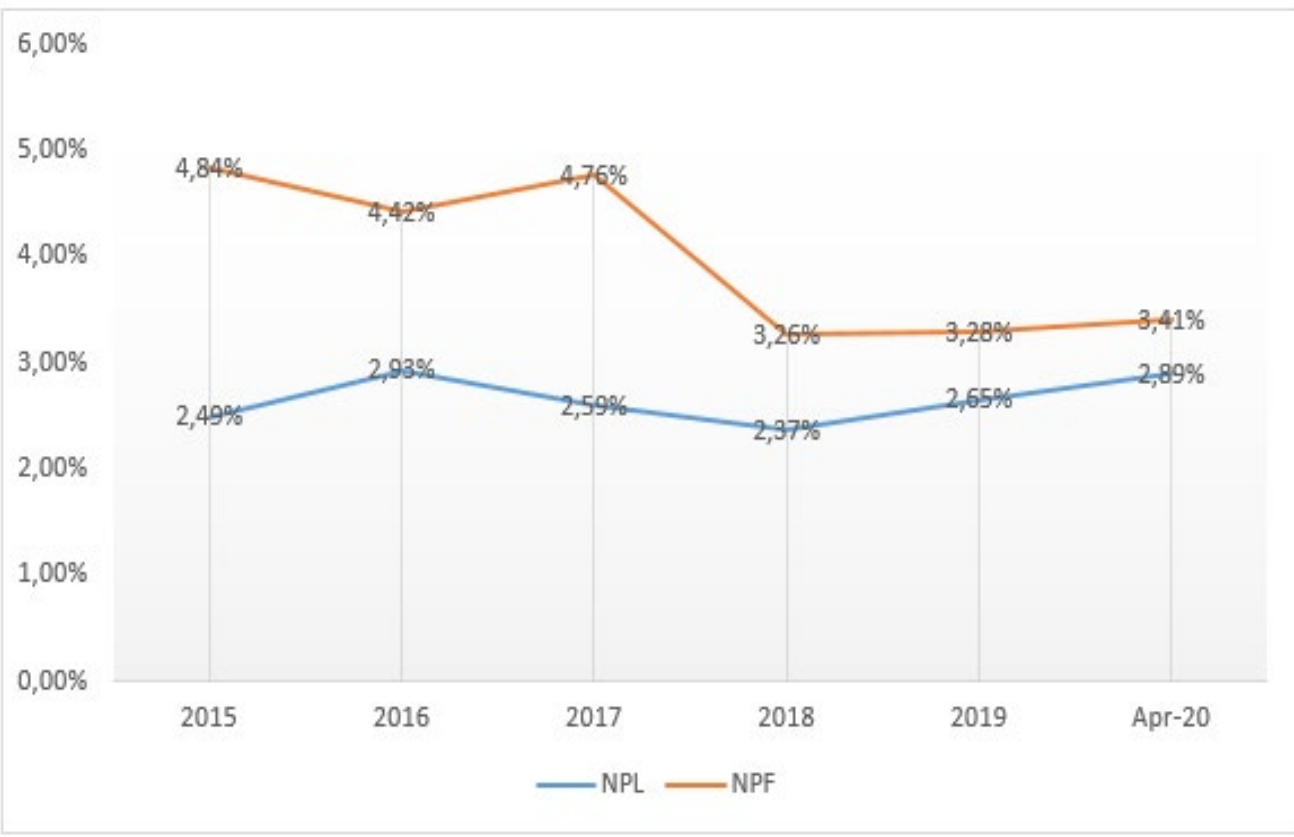

Figure 2

Non Performing Financing/Loan in Islamic Banks and Conventional Banks Source: Indonesian Banking Statistics, 2020 (processed data)

Some studies concluded that macroeconomics plays the most important role as loan risk determinant [8-11]. Beck, Jakubik [12] predicted that the most significant factors that influence Non Performing Loan (NPL) are GDP growth (the main booster over the past decade), stock price, interest rate, and exchange rate. Nkusu [13] found that deterioration in the macroeconomic environment, proxied by slower GDP growth, falling asset price or higher unemployment, is associated with debt service problems. Conversely, improving macroeconomic condition will reduce Non Performing Loan (NPL). Ghosh [14] noted that variables related to rising Non Performing Loan (NPL) are bad quality loan, liquidity risk, inefficiency, capitalization, bank size, unemployment, inflation, and public debt.

The research results by Berger and DeYoung [15] used inefficiency to reveal "bad management". They concluded that efficiency plays important role in rising non performing loan. The research conducted by Koju, Koju [16] showed positive effect of bank size on NPL which means that large banks take 
excessive risks. This finding is consistent with the results [17, 18]. Wang, Huang [19] found that bank size is negatively related to NPL level.

The research results by Tarchouna, Jarraya [20] indicated that non performing loan is influenced by Macroeconomics, Bank Specific and Corporate Governance. Hu, Yang [21], in this research confirmed that banks with higher government shareholding has lower non performing loan. Moreover, bank size is negatively related to Non Performing Loan (NPL). Other researches by Nakano and Nguyen [22] and Switzer and Wang [23] had provided some supports for a relationship between the number of board of directors and loan risk in which the larger number of board of directors resulted in lower loan risk. Stefanelli and Cotugno [24] stated that Independent Commissioners within the banks take role of counterbalance the executives and management where the function is stimulating internal dialogue to reduce the areas of greater conflict of interest.

Indonesia is one of the countries that implements dual banking system namely conventional bank and Islamic bank [25]. As intermediary institution, both conventional bank and Islamic bank still rely on loan or financing as their main income in running their business [26]. The basic difference between both banking system is that conventional bank depends on interest, meanwhile Islamic bank depends on profit and loss sharing principle [27].

Therefore, the objective of this study is to find out the factors that influence NPL and whether there are any differences between NPL in Islamic banks and conventional banks in Indonesia. This study regarding dual banking system namely Islamic and conventional is interesting to be conducted. The three factors existing in some researches $[16,25,27,28]$ will be implemented on dual banking system which the writers think they are different.

\section{Literature Review}

\subsection{Non Performing Financing/Non Performing Loan (NPF/NPL)}

Bank Indonesia Regulation [29] concerning Asset Quality Rating for Islamic Commercial Banks and Islamic Business Units stated that the quality of earning assets in form of financing shall be classified into Current, Special Mention, Sub-standard, Doubtful and Loss. It can be concluded that financing which includes non current financing known as Non Performing Financing (NPF) is the financing that has quality such as special mention, sub-standard, doubtful and loss. Based on Bank Indonesia Circular Letter, Non Performing Loan (NPL) in conventional commercial banks and Non Performing Financing 
(NPF) in Islamic commercial banks are the comparison between problem loan and total loan [30].

A study carried out by Alandejani and Asutay [31] in Gulf States found that certain sectors financed by Islamic banks cause high loan risk; since various financial sectors affect the financing structure and give impact to the long-term risk of Islamic banking [32]. Furthermore, Misman, Bhatti [33] stated that financing quality and ratio model influence risk level of Islamic banking in Malaysia. Islamic banks have more capital which result unstable profits [34].

\subsection{The Difference of Non Performing Loan (NPL) and Non Performing Financing (NPF)}

A number of empirical studies have compared credit risk analysis in conventional banking and Islamic banking. The research conducted by Čihák and Hesse [35] and other researches carried out by Gamaginta [36]; Pappas, Izzeldin [37]; Abedifar, Molyneux [38]; Beck, Demirgüç-Kunt [39] have compared the stability of Islamic banks and conventional banks at different national objects and periods of time. These literature concluded that Islamic banks are more stable. Meanwhile, other researchers did not find the difference of loan/financing risk in conventional banking and Islamic banking. It clearly showed that there are always some variations in the findings resulted from sample banks in various countries and certain period of time [27].

$\mathrm{H}_{1}=$ There is a difference in financing/loan risk between Islamic banks and conventional banks

\subsection{Gross Domestic Product and NPL/NPF}

GDP growth affects bank loan risk, when economy is declining, the GDP is also declining and bank loan risk is increasing [40]. Negative correlation between GDP growth and loan risk can be explained that loan risk will be declined because the capacity of debtors to pay their loan will be better along with the economic development [41]. The study by Dimitrios, Helen [4] in European countries for the period 1990-2015 proved that GDP positively influenced Non Performing Loan. Szarowska [11] in CEE for the period 19992015 attested that the more GDP increase, the more Non Performing Loan (NPL) ratio decreases. Therefore, the second hypothesis $\left(\mathrm{H}_{2}\right)$ will be as follows:

$\mathrm{H}_{2}$ : GDP negatively or positively influence the NPL/NPF 


\subsection{Inflation Rate and NPL/NPF}

The effects of inflation may be ambiguous, on the one hand, higher inflation can ease loan payment by reducing the real amount of loan that has not been paid; on the other hand, it can decrease debtors' real income [11]. The negative effect of inflation on NPL/NPF can be explained by the fact that higher inflation reduces the real amount of loan; therefore, it facilitates debtors in loan payment [2]. In line with Dimitrios, Helen [4]'s study in European countries for the period of 1990-2015, it proved that inflation rate tends to negatively affect Non Performing Loan, but it is not significant. The positive effect of inflation can reduce the capacity of debtors to pay their loan because of the decline in the amount of income amid rising inflation [2]. Inflation is expected to have positive impact on bank loan risk [40]. High Inflation can decrease the real amount of loan that has not been paid so that it facilitates the debtors to pay off their loan it can decline the real amount of income so that the debtors to pay off their loan or it can decline the real amount of income so that the debtors will be more diffcult to pay off their loan [14, 41, 42]. $\mathrm{H}_{3}$ : Inflation rate positively affects the NPL/NPF

\subsection{Efficiency and NPL/NPF}

Following 'skimping' hypothesis by Berger and DeYoung [15], it stated the fact that when there are not too many resources to monitor the loan risk, it saves more costs. This implies the negative effect of efficiency on NPL. On the contrary, cost inefficiency will increase NPL following 'bad management' hypothesis because bank managers with poor skills in the loan assessment and monitoring will increase costs, finally it results poor loan quality [14]. The results of Koju, Koju [16]'s study indicated that inefficiency has positive and significant effects on all models. An increase in operational costs rises inefficiency as well as NPL. The greater cost inefficiency can lead to the increase in NPL, this is because bank managers cannot conduct efficient assessment and monitoring so that it has impact on the loan quality and the increase in expenditure [18, 43-45]. This is our empirical proof supporting 'bad management' hypothesis by Berger and DeYoung [15].

$\mathrm{H}_{4}$ : Efficiency positively affects the NPL/NPF

\subsection{Bank Size and NPL/NPF}

The large banks tend to take excessive risks; therefore, they have higher NPL [46]. The large banks can take advantage from the leniency of 
market discipline set by the regulators; moreover, there is an assumption that the government will protect them in various forms of event [43]. The research result by Koju, Koju [16] showed the positive effect of bank size on NPL which means that the large banks take high risk. This empirical result supports "Too Big Too Fail" effect on the risk taking by Berger and DeYoung [15]. This finding is consistent with the study results by Cotugno, Stefanelli [17], Louzis, Vouldis [18], and Amuakwa-Mensah and Boakye-Adjei [47]. Salas and Saurina [48] and de Lis, Pagés [49] examined the negative relationship between NPL and bank size. They said that the large banks monitor the loans regularly, have better risk management policy and high chance of diversification. The larger banks can be more diversified and have better risk management process. HU, Li [50] stated that the large banks can evaluate the loan quality better because they have higher quality resources. Wang, Huang [19] found that bank size is more potential to improve bank performance in Taiwan. As a result, bank size is negatively related to the NPL level.

$\mathrm{H}_{5}$ : Bank Size negatively influences the NPL/NPF

\subsection{The Size of Board of Directors and NPL/NPF}

The research by Tarchouna, Jarraya [20] stated that corporate governance represented by the board structure variable is board size that affects small banks only, good corporate governance system enables the management to avoid very risky projects; hence, it decreases the NPL level. The bigger number of board of directors enables the greater access to the external environment which can help the banks to reduce uncertainty [51]. Other studies by Nakano and Nguyen [22] in Japanese firms and Switzer and Wang [23] in US banks have supported the fact that the bigger number of board of directors will result in lower loan risk.

$\mathrm{H}_{6}$ : The size of board of directors negatively affects the NPL/NPF

\subsection{The Effect of Independent Commissioners and NPL/NPF}

Some studies such as $[52,53]$ have found the negative effect of independent commissioners on company results. Byrd and Hickman [54] said that supervisory role is carried out by the commissioners outside the company. Previous studies on the effects of Independent Commissioners conducted by Pan [55] and Stefanelli and Cotugno [24] stated that Independent Commissioners in banks take role of counterbalance the executives and management where the function is stimulating internal dialogue to reduce the 
areas of greater conflict of interest. Adnan, Htay [56] stated that Independent Commissioners have relationship with bank efficiency.

$\mathrm{H}_{7}$ : Independent Commissioners negatively influence the NPL/NPF

\section{Research Method}

The population in this study is all Conventional Commercial Banks registered on Indonesia Stock Exchange (IDX) and Islamic Commercial Banks in Indonesia. The sampling in this study used purposive sampling technique in which the criteria are the banks that regularly issued and published complete annual financial statement as of 31 December 2010 to 31 Devember 2018, and conventional commercial banks which are registered on Indonesia Stock Exchange (IDX) no later than 31 December 2010 and listed until 31 December 2018. There were 33 banks obtained as the samples consisting of 24 conventional banks and 9 Islamic banks. Technique of data analysis used in this study is Structural Equation Modeling-Partial Least Square technique and independent sample t-test [57]. The programs used as the device are WarpPLS 6.0 and SPSS 22. Equations used are as follows.

$$
\begin{aligned}
& N P F=\beta_{0}+\beta_{1} G D P_{i t}+\beta_{2} I N F_{i t}+\beta_{3} B S_{i t}+\beta_{4} B O P O_{i t}+\beta_{5} D K I_{i t}+\beta_{6} B D_{i t}+e_{i t} \\
& N P L=\beta_{0}+\beta_{1} G D P_{i t}+\beta_{2} I N F_{i t}+\beta_{3} B S_{i t}+\beta_{4} B O P O_{i t}+\beta_{5} D K I_{i t}+\beta_{6} B D_{i t}+e_{i t}
\end{aligned}
$$

WrapPLS becomes the solution. This program can identify and estimate the relationship among linear variables, the relationship in the form of "s" curve, and the relationship in the form of " $u$ " curve. Therefore, the relationship among variables is more natural [58].

\section{Results}

\subsection{Inner Model}

Inner model evaluation includes model fit test, path coefficient, and $\mathrm{R}^{2}$. Model fit test is used for measuring goodness of fit of a model with data. The following is the result of model fit test and its measurement criteria. 
Table 1

Fit Model

\begin{tabular}{|c|c|c|c|c|c|c|c|c|}
\hline \multirow[t]{2}{*}{ Criteria } & \multicolumn{2}{|c|}{ Cut of Value } & \multicolumn{3}{|c|}{ Conventional Banks } & \multicolumn{3}{|c|}{ Islamic Banks } \\
\hline & Acceptable & Ideal & Value & $\begin{array}{c}\text { P- } \\
\text { Value }\end{array}$ & Desc. & Value & $\begin{array}{c}\text { P- } \\
\text { Value }\end{array}$ & Desc. \\
\hline APC & - & $\begin{array}{c}\mathrm{P}- \\
\text { value } \\
<0.05\end{array}$ & 0.227 & $<0.001$ & Fit & 0.169 & 0.028 & Fit \\
\hline ARS & - & $\begin{array}{c}\mathrm{P}- \\
\text { value } \\
<0.05\end{array}$ & 0.382 & $<0.001$ & Fit & 0.479 & $<0.001$ & Fit \\
\hline AARS & - & $\begin{array}{c}\mathrm{P}- \\
\text { value } \\
<0.05\end{array}$ & 0.364 & $<0.001$ & Fit & 0.437 & $<0.001$ & Fit \\
\hline AVIF & $<=5$ & $<=3.3$ & 1.693 & - & Fit & 1.291 & - & Fit \\
\hline AFVIF & $<=5$ & $<=3.3$ & 1.987 & - & Fit & 1.695 & - & Fit \\
\hline GoF & $\begin{array}{r}\text { Small }>= \\
\text { Medium }>= \\
\text { Large }>=\end{array}$ & $\begin{array}{l}.1 \\
0.25 \\
.36\end{array}$ & 0.618 & - & Large & 0.692 & - & Large \\
\hline SPR & $>=0.7$ & 1 & 0.667 & - & $\begin{array}{c}\text { Relative } \\
\text { Fit }\end{array}$ & 0.833 & - & Fit \\
\hline RSCR & $>=0.9$ & 1 & 0.896 & - & $\begin{array}{c}\text { Relative } \\
\text { Fit }\end{array}$ & 1.000 & - & Fit \\
\hline SSR & $>=0.7$ & - & 1.000 & - & Fit & 1.000 & - & Fit \\
\hline NLBCDR & $>=0.7$ & - & 0.667 & - & $\begin{array}{c}\text { Relative } \\
\text { Fit }\end{array}$ & 0.667 & - & $\begin{array}{c}\text { Relative } \\
\text { Fit }\end{array}$ \\
\hline
\end{tabular}

Source: Data Processed by Writers, 2020

Based on Table 1, all measurement indicators of model adequacy either in conventional commercial banks or Islamic commercial banks stated that the model is fit. Therefore, it can be concluded that the model formed is fit with empirical data and it can be used for interpretation in further discussion.

\subsection{Independent Sample T-Test}

The test using Independent Sample T-test method resulted in Sig (2tailed) of 0.187 which is greater than 0.05 because Confidence Interval of the Difference is $95 \%$. On the basis of that result, Hypothesis $1\left(\mathrm{H}_{1}\right)$, stating that there is significant difference between non performing loan in conventional banks and Islamic banks, is certainly rejected. Based on the output of Independent Sample T-test (Group Statistics), Mean of NPL in Conventional Banks and Mean of NPF in Islamic Banks are 0.040 and 0.032. Thus, in descriptive statistics, it can be concluded that there is difference between non 
performing financing/loan in Islamic banks and conventional banks, but it is not significant indicated by Sig (2-tailed) value of 0.187 in which Mean of non performing financing in Islamic banks is higher than coventional banks.

\subsection{Hypothesis Testing}

Based on the hypotheses mentioned before, the writers tested all those hypotheses. The following is the results of hypothesis testing in conventional commercial banks and Islamic commercial banks.

Table 2

The Results of Hypothesis Testing

\begin{tabular}{|c|c|c|c|c|c|c|c|c|}
\hline & \multirow{2}{*}{$\begin{array}{c}\text { Independent } \\
\text { Variables }\end{array}$} & \multirow{2}{*}{$\begin{array}{l}\text { Dependent } \\
\text { Variables }\end{array}$} & \multicolumn{3}{|c|}{ Conventional Banks } & \multicolumn{3}{|c|}{ Islamic Banks } \\
\hline & & & Value & $\begin{array}{c}\text { P- } \\
\text { Value }\end{array}$ & Desc. & Value & $\begin{array}{c}\text { P- } \\
\text { Value }\end{array}$ & Desc. \\
\hline $\mathrm{H}_{2}$ & GDP & NPL/NPF & 0.116 & 0.042 & Accepted & $\overline{-}$ & 0.091 & Accepted \\
\hline $\mathrm{H}_{3}$ & Inflation & NPL/NPF & 0.049 & 0.235 & Rejected & $\begin{array}{c}- \\
0.016\end{array}$ & 0.444 & Rejected \\
\hline $\mathrm{H}_{4}$ & Efficiency & NPL/NPF & 0.407 & $<0.001$ & Accepted & 0.617 & $<0.001$ & Accepted \\
\hline $\mathrm{H}_{5}$ & Bank Size & NPL/NPF & $0 . \overline{429}$ & $<0.001$ & Accepted & 0.177 & 0.048 & Accepted \\
\hline $\mathrm{H}_{6}$ & $\begin{array}{l}\text { Board of } \\
\text { Directors }\end{array}$ & NPL/NPF & 0.224 & $<0.001$ & Rejected & 0.000 & 0.498 & Rejected \\
\hline $\mathrm{H}_{7}$ & $\begin{array}{l}\text { Independent } \\
\text { Commissioners }\end{array}$ & NPL/NPF & $\begin{array}{c}- \\
0.138\end{array}$ & 0.019 & Accepted & 0.062 & 0.287 & Rejected \\
\hline
\end{tabular}

Source: Data Processed by Writers, 2020

Based on table 2, below are the explanations:

1. Hypothesis 2 stated that Gross Domestic Product negatively or positively influence the NPL/NPF.

a. The testing result in conventional banks showed the coefficient value of 0.116 and $p$-value $=0.042$. The coefficient value indicated that each $1 \%$ increase in GDP will result in the NPL of 0.116 . P-value $=0.042$ significantly influences $\alpha=0.05$, the coefficient value is positive, so the hypothesis is accepted.

b. The testing result in Islamic banks showed the coefficient value of 0.143 and $p$-value $=0.091$. The coefficient value indicated that each $1 \%$ increase in GDP will decline the NPF of 0.143 . P-value $=0.091$ significantly influences $\alpha=0.1$. Therefore, the hypothesis is accepted.

2. Hypothesis 3 stated that Inflation Rate positively affects the NPL/NPF. 
a. The testing result in conventional banks showed the coefficient value $=$ 0.049 and $p$-value $=0.235$. The coefficient value indicated that each $1 \%$ increase in Inflation Rate will result in the NPL of 0.049 . P-value $=$ 0.235 does not affect significantly, so the hypothesis is rejected.

b. The testing result in Islamic banks showed the coefficient value = 0.016 and $p$-value $=0.444$. The coefficient value indicated that each $1 \%$ increase in Inflation will decrease the NPF of 0.016 . P-value $=$ 0.444 does not affect significantly, so the hypothesis is rejected.

3. Hypothesis 4 stated that Efficiency (BOPO) positively affects the NPL/NPF.

a. The testing result in conventional banks showed the coefficient value $=$ 0.407 and $p$-value $<0.001$. The coefficient value indicated that each $1 \%$ increase in BOPO will increase the NPL of 0.016. P-value $<0.001$ affects significantly; therefore, the hypothesis is accepted.

b. The testing result in Islamic banks showed the coefficient value = 0.617 and $p$-value $<0.001$. The coefficient value indicated that each $1 \%$ increase in BOPO will increase the NPF of 0.617. P-value $<0.001$ affects significantly; thus, the hypothesis is accepted.

4. Hypothesis 5 stated that Bank Size negatively influences the NPL/NPF.

a. The testing result in conventional banks showed the coefficient value $=$ -0.429 and $p$-value $<0.001$. The coefficient value indicated that each $1 \%$ increase in Bank Size will decline the NPL of 0.429. P-value $<0.001$ influences significantly, so the hypothesis is accepted.

b. The testing result in Islamic banks showed the coefficient value = 0.177 and $p$-value $=0.048$. The coefficient value indicated that each $1 \%$ increase in Bank Size will decline the NPF of 0.177. P-value $=$ 0.048 influences significantly; hence, the hypothesis is accepted.

5. Hypothesis 6 stated that the Size of Board of Directors negatively affects the NPL/NPF.

a. The testing result in conventional banks showed the coefficient value $=$ 0.224 and $p$-value $<0.001$. The coefficient value indicated that each $1 \%$ increase in the Size of Board of Directors will increase the NPL of 0.224 . P-value $<0.001$ affects significantly, but the coefficient value is positive so that the hypothesis is rejected.

b. The testing result in Islamic banks showed the coefficient value = 0.000 and $p$-value $=0.498$. The coefficient value indicated that each $1 \%$ increase in the Size of Board of Directors will decrease the NPF of 0.000 . P-value $=0.498$ does not affect significantly, so the hypothesis is rejected. 
6. Hypothesis 7 stated that Independent Commissioners negatively influence the NPL/NPF.

a. The testing result in conventional banks showed the coefficient value $=$ -0.138 and $p$-value $=0.019$. The coefficient value indicated that each $1 \%$ increase in Independent Comissioners will decline the NPL of 0.138. P-value $=0.019$ influences significantly; therefore, the hypothesis is accepted.

b. The testing result in Islamic banks showed the coefficient value = 0.062 and $p$-value $=0.287$. The coefficient value indicated that each $1 \%$ increase in Independent Comissioners will increase the NPF of 0.062 . P-value $=0.287$ does not influence significantly; thus, the hypothesis is rejected.

\section{Discussion}

Based on the hypothesis testing conducted, the result is in accordance with [27] in which no significant difference is found in loan risk between two banking systems during the financial crisis. This indicated that the two banking systems experience the same matter and deny the claim that Islamic banks have better performance than conventional banks. Islamic banks have much lower financing risk than conventional banks if it is measured by Distance to Default (DD), conversely, Islamic banks have higher financing risk when using Z-score ratio and NPL ratio [27].

Based on the hypothesis testing, hypothesis $2(\mathrm{H} 2)$ in conventional banks and Islamic banks is accepted. In conventional banks, the hypothesis testing obtained the result that hypothesis 2 (H2) is accepted. This is in line with the research by Dimitrios, Helen [4] in European countries for the period of 1990-2015. It proved that Gross Domestic Product positively influence Non Performing Loan. In Islamic banks, hypothesis $2(\mathrm{H} 2)$ is also accepted. This is in harmony with the research by Koju, Koju [16] indicating that GDP growth rate is significantly negative. It showed that the increase in GDP creates job opportunities which finally rise the income of the debtors and reduce non performing financing. Kuzucu and Kuzucu [41]'s study found that GDP had significant influence on non performing financing before financial crisis in 2007 and after financial crisis in 2008.

Based on the hypothesis testing, hypothesis $3(\mathrm{H} 3)$ in conventional banks and Islamic banks is rejected. The positive result can be explained by the fact that inflation reduces repayment capacity and positively influences the NPL in term of interest rate [2]. According to Koju, Koju [16], inflation rate negatively showed that the increase in inflation rate declines the real amount 
of loan and reduces non performing loan. Because of rising debt per capita, debt burden increases, which finally decreases economic growth so that the NPL increases. Debt per capita is positively related to non performing loan.

Based on the hypothesis testing, hypothesis 4 (H4) in conventional banks and Islamic banks is accepted. This result confirmed 'bad management' hypothesis by Berger and DeYoung [15] and this finding is consistent with the studies by Espinoza and Prasad [59] for GCC countries; Louzis, Vouldis [18] for Bank of Greece; and Podpiera and Weill [45] for Bank of Czech. This findings proved that good management is really required to improve loan quality. The positive effect of the efficiency on NPL showed unfavorable thing for management in banking system, so it can cause banking crisis [16]. Higher cost inefficiency will increase the NPL following the 'bad management' hypothesis since bank managers with poor skills in loan assessment and monitoring will increase costs and provide bad quality loan [14].

Based on the hypothesis testing, hypothesis 5 (H5) in conventional banks and Islamic banks is accepted. This result supports the research conducted by Salas and Saurina [48] and de Lis, Pagés [49] which found the negative relationship between NPL and bank size. Based on those researches, the large banks monitor the loans regularly, have better risk management policy and high chance of diversification. The larger banks can be more diversified and have better risk management proces. HU, Li [50] stated that the large banks can evaluate the loan quality better because they have higher quality resources. Wang, Huang [19] found that bank size is more potential to improve bank performance in Taiwan. As a result, bank size is negatively related to the NPL level.

Based on the hypothesis testing, hypothesis 6 (H6) in conventional banks and Islamic banks is rejected. The research result in Islamic banks is in line with [60] that stated board size is negatively and significantly related to the NPF. The finding of board size has negative relationship with financing risk in line with Switzer and Wang [23]'s study in the context of US banks. In other words, the company that have many board members tend to take management decision of less risky financing and as a result, it reduces financing risk level. Meanwhile, in conventional banks, the research result is in harmony with the research conducted by Nguyen, Rahman [61] which found that board size shows positive and significant relationship with non performing loan. The result of this research on board size is consistent with the previous studies carried by [61, 62] and [61, 62].

Based on the hypothesis testing, hypothesis 7 (H7) is accepted in conventional banks and rejected in Islamic banks. In conventional banks, the research result is in line with the study by Nguyen, Rahman [61] which stated 
that independent commissioners have negative relationship with non performing loan and are consistent with literature [63] indicating the positive relationship between independent commissioners with company performance. The research result in Islamic banks is in harmony with the research by [60] which found that independent commissioners have positive and significant relationship with financing risk. The result is surprising and interesting because the previous evidence indicated that independent commissioners are negatively related to the final result and risk taking [52] .

\section{Conclusion, Limitation, and Implications}

The objective of this study is to compare loan/financing risk and the factors that influence it between conventional banks and Islamic banks in Indonesia from 2010 to 2018 . The results of the study showed that GDP affect the increase in NPL and the decrease in NPF. Inflation has no influence on NPL and NPF. Efficiency affects the increase in NPL and NPF. Bank size has effect on the decline of NPL and NPF. Board of directors influence the increase in NPL, but having no effect on NPF. Independent commissioners affect the decline of NPL, but having no influence on NPF.

The research results, the most important determinants of NPL/ NPF are represented by specific bank variables that must be anticipated for their effect on NPL / NPF in Islamic and conventional banking. This variable is efficiency (BOPO). BOPO has the greatest influence on the NPL / NPF of conventional and Islamic banks. Bank operating costs that are too high or equal to operating income will not bring profit to the bank. High bank income with low operating costs can reduce the BOPO ratio so that the bank is in a healthy position, which means that the tendency to minimize the occurrence of problematic financing can be overcome. Things that banks can do to reduce operational costs include increasing the portion of savings and current accounts, optimizing the role of information technology, and cutting general and administrative costs.

This research has limitations that it is only carried out in the Islamic and conventional banking industry from 2010 to 2018. The variables used only come from macroeconomic variables, bank specifications, and corporate governance. The only variable used in measuring credit / financing risk uses the NPF / NPL ratio. Based on the limitations of the research described above, for further research the authors provide the following suggestions: Research can use market monitoring variables which can be proxied by credit ratings and public registries as determinants of non-performing loans/financing, to 
measure credit / financing risk can also use the z-score ratio and measured by DD (Distance to Default).

\section{Acknowledgement}

We would like to express our greatest gratitude to Bandung State Polytechnic.

\section{References}

[1] Kjosevski J, Petkovski M, Naumovska E. Bank-specific and macroeconomic determinants of non-performing loans in the Republic of Macedonia: Comparative analysis of enterprise and household NPLs. Economic research-Ekonomska istraživanja. 2019;32(1):1185-203.

[2] Kjosevski J, Petkovski M. Non-performing loans in Baltic States: determinants and macroeconomic effects. Baltic Journal of Economics. 2017;17(1):25-44.

[3] Saif-Alyousfi AY, Saha A, Md-Rus R. Impact of oil and gas price shocks on the nonperforming loans of banks in an oil and gas-rich economy. International Journal of Bank Marketing. 2018.

[4] Dimitrios A, Helen L, Mike T. Determinants of non-performing loans: Evidence from Euro-area countries. Finance research letters. 2016;18:116-9.

[5] Ozili PK. Non-performing loans and financial development: new evidence. The Journal of Risk Finance. 2019.

[6] OJK OJK. 15/POJK. 03/2017 Tentang. Penetapan Status Dan Tindak Lanjut Pengawasan Bank Umum. 2018.

[7] Hassan MK, Khan A, Paltrinieri A. Liquidity risk, credit risk and stability in Islamic and conventional banks. Research in International Business and Finance. 2019;48:1731.

[8] Bonfim D. Credit risk drivers: Evaluating the contribution of firm level information and of macroeconomic dynamics. Journal of Banking \& Finance. 2009;33(2):281-99.

[9] Kattai R. Credit risk model for the Estonian banking sector: Eesti Pank; 2010.

[10] Castro V. Macroeconomic determinants of the credit risk in the banking system: The case of the GIPSI. Economic Modelling. 2013;31:672-83.

[11] Szarowska I. Effect of macroeconomic determinants on non-performing loans in Central and Eastern European countries. International Journal of Monetary Economics and Finance. 2018;11(1):20-35.

[12] Beck R, Jakubik P, Piloiu A. Key determinants of non-performing loans: new evidence from a global sample. Open Economies Review. 2015;26(3):525-50.

[13] Nkusu MM. Nonperforming loans and macrofinancial vulnerabilities in advanced economies: International Monetary Fund; 2011.

[14] Ghosh A. Sector-specific analysis of non-performing loans in the US banking system and their macroeconomic impact. Journal of Economics and Business. 2017;93:2945.

[15] Berger AN, DeYoung R. Problem loans and cost efficiency in commercial banks. Journal of Banking \& Finance. 1997;21(6):849-70.

[16] Koju L, Koju R, Wang S. Macroeconomic and Bank-Specific Determinants of NonPerforming Loans: Evidence from Nepalese Banking System. Journal of Central Banking Theory and Practice. 2018;7(3):111-38. 
[17] Cotugno M, Stefanelli V, Torluccio G, editors. Bank intermediation models and portfolio default rates: what's the relation? 23rd Australasian Finance and Banking Conference; 2010.

[18] Louzis DP, Vouldis AT, Metaxas VL. Macroeconomic and bank-specific determinants of non-performing loans in Greece: A comparative study of mortgage, business and consumer loan portfolios. Journal of Banking \& Finance. 2012;36(4):1012-27.

[19] Wang K, Huang W, Wu J, Liu Y-N. Efficiency measures of the Chinese commercial banking system using an additive two-stage DEA. Omega. 2014;44:5-20.

[20] Tarchouna A, Jarraya B, Bouri A. How to explain non-performing loans by many corporate governance variables simultaneously? A corporate governance index is built to US commercial banks. Research in International Business and Finance. 2017;42:645-57.

[21] $\mathrm{Hu}$ J, Yang L, Yung-Ho C. Ownership and Nonperforming Loans: Evidence from Taiwan's Banks. Developing Economies. Forthcoming at the reference paper. 2006.

[22] Nakano M, Nguyen P. Board Size and Corporate Risk Taking: Further Evidence from J apan. Corporate Governance: An International Review. 2012;20(4):369-87.

[23] Switzer LN, Wang J. Default risk estimation, bank credit risk, and corporate governance. Financial Markets, Institutions \& Instruments. 2013;22(2):91-112.

[24] Stefanelli V, Cotugno M. An empirical analysis on board monitoring role and loan portfolio quality measurement in banks. Academy of Banking Studies Journal. $2012 ; 11$.

[25] Trad N, Trabelsi MA, Goux JF. Risk and profitability of Islamic banks: A religious deception or an alternative solution? European Research on Management and Business Economics. 2017;23(1):40-5.

[26] Ascarya DY. Bank Syariah: Gambaran Umum. Jakarta: Pusat Pendidikan dan Studi Kebanksentralan (PPSK) Bank Indonesia. 2005.

[27] Kabir MN, Worthington A, Gupta R. Comparative credit risk in Islamic and conventional bank. Pacific-Basin Finance Journal. 2015;34:327-53.

[28] Amin AS, Imam MO, Malik M. Regulations, governance, and resolution of nonperforming loan: Evidence from an emerging economy. Emerging Markets Finance and Trade. 2019;55(10):2275-97.

[29] Indonesia B. Peraturan Bank Indonesia Nomor 13. 2011.

[30] Indonesia SEB. Kredir Perbankan. Nomor 12/11/DPNP tanggal 31 Maret 2010, Lampiran 14, 2010.

[31] Alandejani M, Asutay M. Nonperforming loans in the GCC banking sectors: Does the Islamic finance matter? Research in International Business and Finance. 2017;42:832-54.

[32] Abdul-Rahman A, Sulaiman AA, Said NLHM. Does financing structure affects bank liquidity risk? Pacific-Basin Finance Journal. 2018;52:26-39.

[33] Misman FN, Bhatti I, Lou W, Samsudin S, Rahman NHA. Islamic banks credit risk: a panel study. Procedia Economics and Finance. 2015;31:75-82.

[34] Bitar $M$, Madiès $P$, Taramasco $O$. What makes Islamic banks different? A multivariate approach. Economic Systems. 2017;41(2):215-35.

[35] Čihák M, Hesse H. Islamic banks and financial stability: An empirical analysis. Journal of Financial Services Research. 2010;38(2-3):95-113. 
[36] Gamaginta RR. The stability comparison between Islamic banks and conventional banks: Evidence in Indonesia. Financial stability and risk management in Islamic financial institutions. 2015:101.

[37] Pappas V, Izzeldin M, Fuertes A, Ongena S. A survival analysis of Islamic bank failure risk. Journal of Financial Services Research. 2012;51:221-56.

[38] Abedifar P, Molyneux P, Tarazi A. Risk in Islamic banking. Review of Finance. 2013;17(6):2035-96.

[39] Beck T, Demirgüç-Kunt A, Merrouche O. Islamic vs. conventional banking: Business model, efficiency and stability: The World Bank; 2010.

[40] Tanasković S, Jandrić M. Macroeconomic and institutional determinants of nonperforming loans. Journal of Central Banking Theory and Practice. 2015;4(1):47-62.

[41] Kuzucu N, Kuzucu S. What drives non-performing loans? Evidence from emerging and advanced economies during pre-and post-Global Financial Crisis. Emerging Markets Finance and Trade. 2019;55(8):1694-708.

[42] Chaibi H, Ftiti Z. Credit risk determinants: Evidence from a cross-country study. Research in international business and finance. 2015;33:1-16.

[43] Kumar M, Goel V, Jain T, Singhal S, Goel LM. Neural network approach to loan default prediction. International Research Journal of Engineering and Technology (IRJET). 2018;5(4):4231-4.

[44] Lee YY, Yahya MHDH, Habibullah MS, Ashhari ZM. Non-performing loans in European Union: country governance dimensions. Journal of Financial Economic Policy. 2019.

[45] Podpiera J, Weill L. Bad luck or bad management? Emerging banking market experience. Journal of financial stability. 2008;4(2):135-48.

[46] Warninda TD, Ekaputra IA, Rokhim R. Do Mudarabah and Musharakah financing impact Islamic Bank credit risk differently? Research in International Business and Finance. 2019;49:166-75.

[47] Amuakwa-Mensah F, Boakye-Adjei A. Determinants of non-performing loans in Ghana banking industry. International Journal of Computational Economics and Econometrics. 2015;5(1):35-54.

[48] Salas V, Saurina J. Credit risk in two institutional regimes: Spanish commercial and savings banks. Journal of Financial Services Research. 2002;22(3):203-24.

[49] de Lis SF, Pagés JM, Salas JS. Credit growth, problem loans and credit risk provisioning in Spain: Banco de España, Servicio de Estudios; 2000.

[50] HU JL, Li Y, CHIU YH. Ownership and nonperforming loans: Evidence from Taiwan's banks. The Developing Economies. 2004;42(3):405-20.

[51] Jia C. The effect of ownership on the prudential behavior of banks-The case of China. Journal of Banking \& Finance. 2009;33(1):77-87.

[52] Pathan S. Strong boards, CEO power and bank risk-taking. Journal of banking \& finance. 2009;33(7):1340-50.

[53] Zhong X, Yan S, Xiaokang W, Minggao S. Market Structure and Banking Industry Performance in China [J]. Economic Research Journal. 2009;10.

[54] Byrd JW, Hickman KA. Do outside directors monitor managers?: Evidence from tender offer bids. Journal of financial economics. 1992;32(2):195-221.

[55] Pan Z. An Empirical Analysis of the Impact of Commercial Banks' Corporate Governance to Risk Control. Management \& Engineering. 2016(22):72. 
[56] Adnan MA, Htay SNN, Rashid HMA, Meera AKM. A panel data analysis on the relationship between corporate governance and bank efficiency. Journal of Accounting. 2011;1(1).

[57] Baltagi BH. Econometric analysis of data panel. England: John Wiley \& Sons Ltd. 2005 .

[58] Gujarati DN, Porter DC. Dasar-Dasar Ekonometrika, Edisi 5. Jakarta: Salemba Empat. 2012.

[59] Espinoza RA, Prasad A. Nonperforming loans in the GCC banking system and their macroeconomic effects: International Monetary Fund; 2010.

[60] Lu J, Boateng A. Board composition, monitoring and credit risk: evidence from the UK banking industry. Review of Quantitative Finance and Accounting. 2018;51(4):1107-28.

[61] Nguyen P, Rahman N, Tong A, Zhao R. Board size and firm value: Evidence from Australia. Journal of Management \& Governance. 2016;20(4):851-73.

[62] Bennedsen M, Kongsted HC, Nielsen KM. The causal effect of board size in the performance of small and medium-sized firms. Journal of Banking \& Finance. 2008;32(6):1098-109.

[63] Klein A. Audit committee, board of director characteristics, and earnings management. Journal of accounting and economics. 2002;33(3):375-400. 